\title{
Synthesis and Characterization of Phosphido-Monolayer-Protected Gold Nanoclusters
}

Diana M. Stefanescu, ${ }^{a}$ David S. Glueck, ${ }^{\text {*a }}$ Renée Siegel, ${ }^{\mathrm{b}}$ and Roderick E. Wasylishen ${ }^{\mathrm{b}}$

${ }^{a} 6128$ Burke Laboratory, Department of Chemistry and Center for Nanomaterials Research, Dartmouth College, Hanover, New Hampshire, $03755^{b}$ Department of Chemistry, University of Alberta, Edmonton, Alberta, Canada, T6G 2 G2

\section{Supporting Information}

\section{Synthesis and Characterization of Au-phosphido MPCs \\ 2. Monitoring Cluster Synthesis by ${ }^{31} \mathrm{P}$ NMR Spectroscopy \\ 3. Reactions of the Clusters with Dodecanethiol \\ 4. Reactions of the Clusters with lodine}

General Experimental Details. Unless otherwise noted, all solution NMR spectra were recorded on a Varian 300 or $500 \mathrm{MHz}$ spectrometer. ${ }^{1} \mathrm{H}$ NMR shifts are reported relative to $\mathrm{Me}_{4} \mathrm{Si}$ and were determined by reference to the solvent peak. ${ }^{31} \mathrm{P}$ NMR chemical shifts are reported relative to $\mathrm{H}_{3} \mathrm{PO}_{4}(85 \%)$ used as an external reference. Solid state NMR spectra were recorded at the University of Alberta on a Chemagnetics CMX-200 or Bruker Avance 300 spectrometer. The experimental parameters were usually set between the following values: spinning rate: $5-15 \mathrm{kHz}$, recycle delay: $2-5 \mathrm{~s},{ }^{1} \mathrm{H}$ rf field $\sim 50-60 \mathrm{kHz}$, contact times: $0.5-3 \mathrm{~ms}$. IR spectra were recorded on $\mathrm{KBr}$ pellets using a Perkin Elmer 1600 series FTIR instrument.

The TEM images of the particles were obtained with a JEOL 2000FX microscope. TEM samples were prepared by adding one drop of $1 \mathrm{mg}$ cluster $/ 1 \mathrm{~mL}$ toluene solution on 400 mesh carbon coated copper grids. The microscope was operated at $120 \mathrm{kV}$ in order to obtain a better contrast. After examination of several grids to find where particles could be observed as distinct features, typical regions of the sample were imaged at a magnification of 150-250K. Size distributions of the gold clusters were obtained from typical regions of digitized photographic enlargements using NIH Image (available at http://rsb.info.nih.gov/nih-image). The particles usually have an elliptical shape. The major and minor axes were measured and their average is reported as the diameter of the particle. Statistical size distributions, as well as standard deviations, were calculated and plotted using Kaleidagraph (available at www.kaleidagraph.com). For a given cluster sample, the average diameter of the gold core and its standard deviation are reported: ave. \pm s.d.

TGA experiments were done on a TA Instruments $Q$ 50-0135 machine. In TGA, about $2-16 \mathrm{mg}$ of cluster were heated in air to $800^{\circ} \mathrm{C}$, at a rate of $20^{\circ} \mathrm{C} / \mathrm{min}$. The initial black color of the cluster disappeared and only gold could be observed at the end of the heating. XPS spectra were done on a Perkin-Elmer PHI 5100 spectrometer. The UV- 
VIS spectra were recorded on a Hewlett Packard 8451A diode array spectrophotometer. A solution of 2-3 mg of gold cluster in $20 \mathrm{~mL}$ of $\mathrm{CH}_{2} \mathrm{Cl}_{2}$ was used.

Matrix Assisted Laser Desorption Ionization time-of-flight mass spectra (MALDITOFMS) were recorded on a PerSeptive Biosystems Voyager-DE STR spectrometer at the University of Illinois Urbana-Champaign (http://www.scs.uiuc.edu/ msweb). HABA or sinapinic acid was employed as the matrix. The samples were dissolved in toluene and diluted in the matrix. $1 \mu \mathrm{L}$ of the mix was deposited on the target. The targets were allowed to air-dry. The accelerating voltage was set to $25 \mathrm{kV}$, the delayed extraction grid was set to $93 \%$, and the extraction delay was set to 400 nanoseconds. The $\mathrm{N}_{2}$ laser power (337 nM) was set to the minimum power necessary to produce spectra with good signal-to-noise ratio. The mass scale was calibrated using a mixture of bovine insulin (5734 Da M+H) and trypsinogen (23981 Da M+H).

Deionized, nanopure (resistivity $>18 \mathrm{M} \Omega$ ) water obtained from a Modulab Analytical research grade UF purifier was used. Filtration was done in the glovebox on a fine frit. Where cannula filtration was necessary, the filter paper used was Magna nylon supported plain, 45 micron, $90 \mathrm{~mm}$ from Fisher.

The percent yield of the nanoclusters is reported based on gold. Knowing the yield of nanocluster product and the percent gold (from TGA) in that sample, we can calculate the amount of gold it contains. Dividing this value by the amount of gold in the starting material gives the percent yield based on gold. For example, for the synthesis of $\mathrm{Au}_{\mathrm{x}}\left(\mathrm{PMes}_{2}\right)_{\mathrm{y}}, 3 \mathrm{mmol}$ of $\mathrm{HAuCl}_{4} \cdot 3 \mathrm{H}_{2} \mathrm{O}(3 \mathrm{mmol} \mathrm{Au}, 590 \mathrm{mg})$ gave $658 \mathrm{mg}$ of product with $60.96 \%$ Au content $(401 \mathrm{mg} \mathrm{Au})$. The yield is then $(401 \mathrm{mg} / 590 \mathrm{mg}) \times 100=68 \%$.

Unless otherwise noted, reagents were from commercial suppliers. PHMes ${ }_{2},{ }^{1}$ $\mathrm{PH}(\mathrm{Ph}) \mathrm{Mes},{ }^{2}$ and the oligomers $\left[\mathrm{Au}\left(\mathrm{PR}_{2}\right)_{n}\right]^{3}$ were prepared according to the literature.

All syntheses and manipulations of Au MPCs (except column chromatography and recrystallization of the eluted clusters) were performed under $\mathrm{N}_{2}$ using standard Schlenk and drybox techniques.

\section{Synthesis and Characterization of Au-phosphido MPCs}

$\mathrm{Au}_{\mathrm{x}}\left(\mathrm{PMes}_{2}\right)_{\mathrm{y}}(\mathbf{1})$ See the Experimental section. 
Figure S1. Solid-state ${ }^{31} \mathrm{P}$ NMR spectrum of as-prepared $A u_{x}\left(\mathrm{PMes}_{2}\right)_{y}$.

AuPMes2 clusters: impure

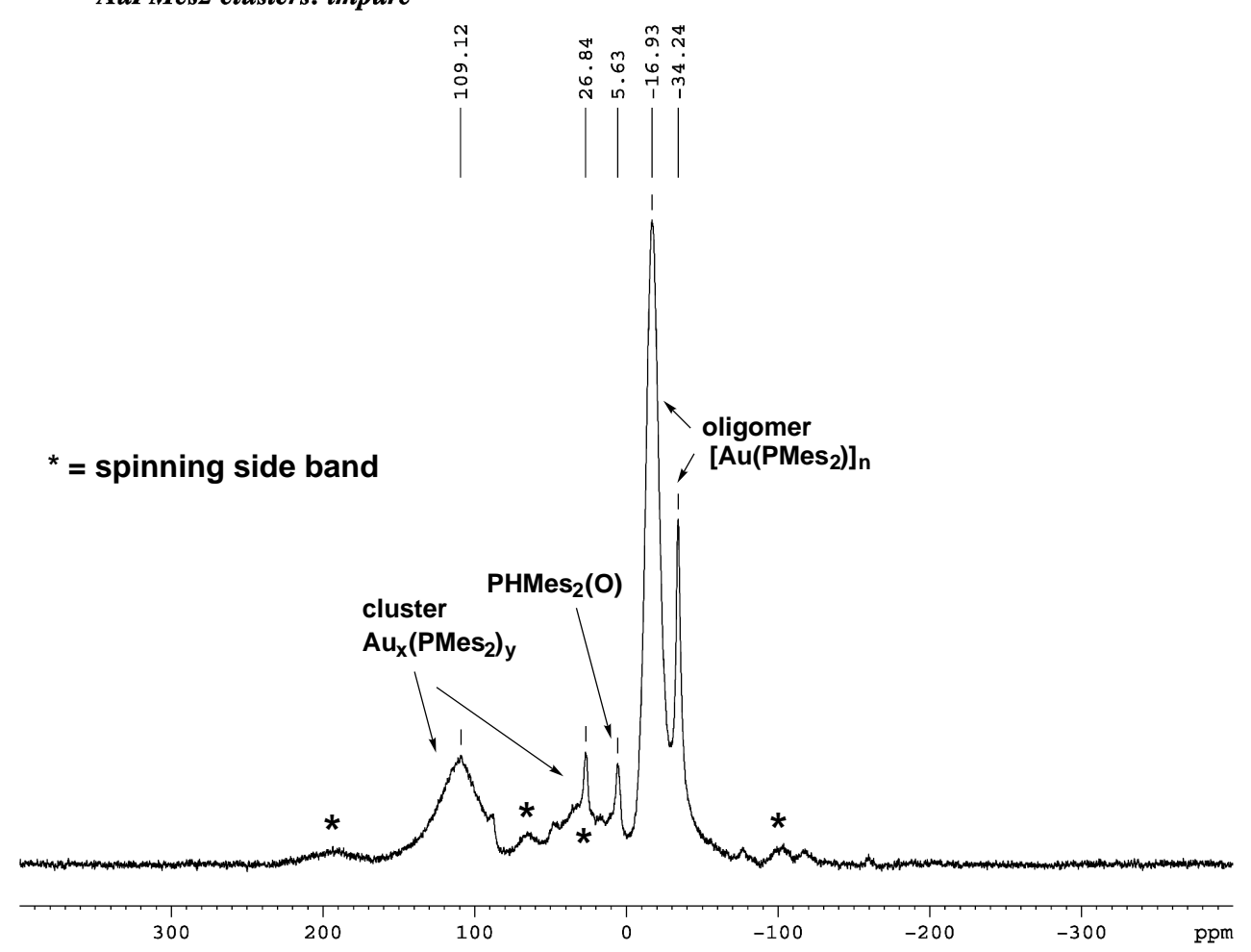

Figure S2. Solid-state ${ }^{31} \mathrm{P} N M R$ spectrum of $\mathrm{Au}_{\mathrm{x}}\left(\mathrm{PMes}_{2}\right)_{\mathrm{y}}$ after chromatography. Peak assignments are as in Figure S1; the origin of the peak at $0.8 \mathrm{ppm}$ is unknown.

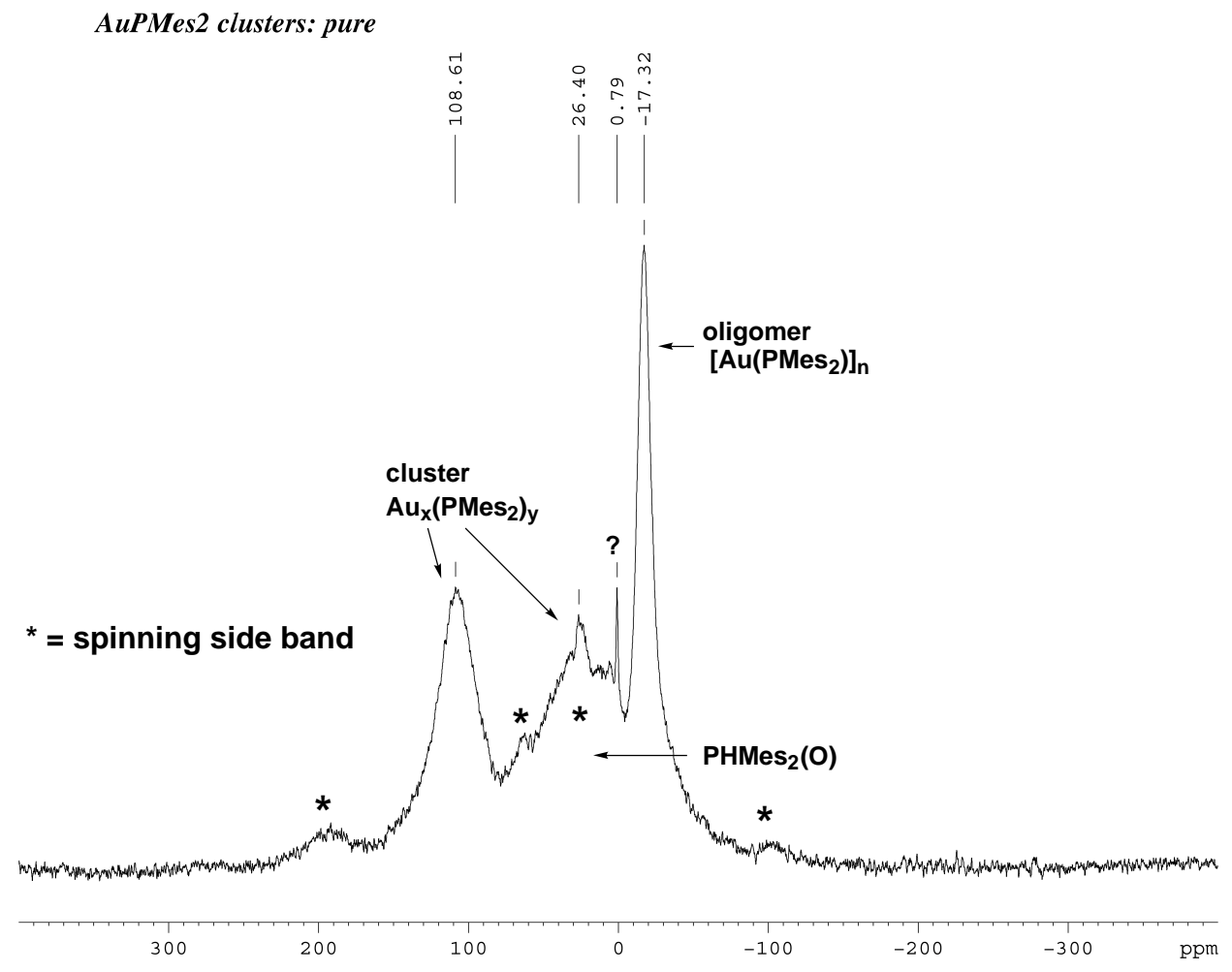




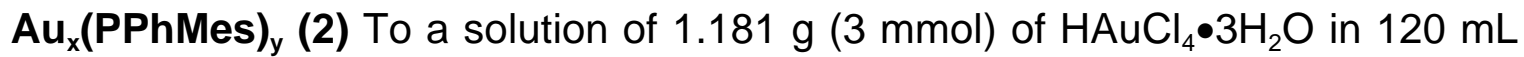
of THF and $75 \mathrm{~mL}$ of water, $0.685 \mathrm{~g}$ (3 mmol) of $\mathrm{PH}(\mathrm{Ph})(\mathrm{Mes})$ in $30 \mathrm{~mL}$ of THF and 30 $\mathrm{mL}$ of water was added under $\mathrm{N}_{2}$ and the mixture was stirred for $10 \mathrm{~min}$. The solution turned orange and became more turbid. To this mixture, a solution of $0.90 \mathrm{~g}(24 \mathrm{mmol})$ of $\mathrm{NaBH}_{4}$ in $30 \mathrm{~mL}$ of water was added under $\mathrm{N}_{2}$ and the mixture was stirred for $3 \mathrm{~h}$. The solution turned dark brown. To separate the organic from the aqueous phase 60 $\mathrm{mL}$ of toluene was added. The toluene was evaporated yielding a black solid, which was suspended in $10 \mathrm{~mL}$ of acetonitrile, then vacuum filtered and washed with $60 \mathrm{~mL}$ of acetonitrile. The yield was $298 \mathrm{mg}, 33 \%$.

${ }^{1} \mathrm{H}$ NMR $\left(\mathrm{C}_{6} \mathrm{D}_{6}\right): \delta 7.8$ (broad), 6.78 (broad), 2.92-1.55 $(\mathrm{m})$, overlap of broad and sharp peaks

${ }^{31} \mathrm{P}\left\{{ }^{1} \mathrm{H}\right\} \operatorname{NMR}\left(\mathrm{C}_{6} \mathrm{D}_{6}\right): \delta-7.7,-17.2$ showing the presence of $[\mathrm{Au}(\mathrm{P}(\mathrm{Ph})(\mathrm{Mes}))]_{\mathrm{n}}$ as impurity. TEM: $\mathrm{d}(\mathrm{nm})=1.10 \pm 0.29$

XPS: $A u: P=1.7: 1$

TGA: $66.19 \%$ Au, Au:P = 2.3:1

On a similar sample

MALDI TOF-MS (HABA): several maxima $\mathrm{m} / \mathrm{z}$ at 3376, 6132, and $7881 . \mathrm{m} / \mathrm{z}$ calculated for $\mathrm{Au}_{38}(\mathrm{PPhMes})_{16}$ (see below) is 11,121 .

To separate $[\mathrm{Au}(\mathrm{P}(\mathrm{Ph})(\mathrm{Mes}))]_{\mathrm{n}}$ from $\mathrm{Au}_{\mathrm{x}}(\mathrm{P}(\mathrm{Ph})(\mathrm{Mes}))_{\mathrm{y}}$, a sample of $96 \mathrm{mg}$ of assynthesized $\mathrm{Au}_{\mathrm{x}}(\mathrm{P}(\mathrm{Ph})(\mathrm{Mes}))_{\mathrm{y}}$ was dissolved in $3 \mathrm{~mL}$ of toluene and loaded onto a silica column $(19 \times 400 \mathrm{~mm})$. $500 \mathrm{~mL}$ of a $4: 1$ mixture of hexane and toluene was used to separate the oligomer impurity from the cluster. A clear solution was eluted, yielding a white-yellow solid after solvent evaporation (4 mg of $[\mathrm{Au}(\mathrm{P}(\mathrm{Ph})(\mathrm{Mes}))]_{\mathrm{n}}, 4.1 \%$ by weight, $\left.{ }^{31} \mathrm{P}\left\{{ }^{1} \mathrm{H}\right\} \operatorname{NMR}\left(\mathrm{C}_{6} \mathrm{D}_{6}\right): \delta-12.1,-21.5\right)$. The clusters remained on the column.

The column was washed with $100 \mathrm{~mL}$ of ethyl acetate and then with $100 \mathrm{~mL}$ of ethanol until the eluted solutions turned from black to a faint brown color. The solvent was evaporated under vacuum yielding a black solid which was recrystallized from toluene and acetonitrile. Some black material was still present on the column, but it could not be removed. Recovery was $30 \mathrm{mg}, 31 \%$ by weight. The resulting material was characterized by ${ }^{1} \mathrm{H}$ NMR, IR, TEM, XPS, TGA, and mass spectroscopy.

${ }^{1} \mathrm{H}$ NMR $\left(\mathrm{C}_{6} \mathrm{D}_{6}\right): \delta 7.82$ (broad, Ar), 6.64 (broad, Ar), 2.70 (broad, Me), 2.07 (broad, Me) ${ }^{31} \mathrm{P}\left\{{ }^{1} \mathrm{H}\right\} \operatorname{NMR}\left(\mathrm{C}_{6} \mathrm{D}_{6}\right)$ : no peak was observed

IR $\left(\mathrm{KBr}, \mathrm{cm}^{-1}\right): 3056,3011,2922,2856,1728,1600,1433,1100,1022,744,694,622$, 556

TEM: $\mathrm{d}(\mathrm{nm})=1.07 \pm 0.23$

XPS: $A u: P=2.2: 1$

TGA: $67.38 \% A u, A u: P=2.4: 1$

MALDI TOF-MS (HABA): maximum at $\mathrm{m} / \mathrm{z} 8048$. Calculated $\mathrm{m} / \mathrm{z}$ for $\mathrm{Au}_{38}(\mathrm{P}(\mathrm{Ph})(\mathrm{Mes}))_{16}$ is 11,121 .

$\mathrm{Au}_{\mathbf{x}}\left(\mathrm{PCy}_{2}\right)_{\mathbf{y}}$ (3) To a solution of $1.181 \mathrm{~g}(3 \mathrm{mmol})$ of $\mathrm{HAuCl}_{4} \cdot 3 \mathrm{H}_{2} \mathrm{O}$ in $120 \mathrm{~mL}$ of THF and $75 \mathrm{~mL}$ of water, $0.593 \mathrm{~g}$ of $\mathrm{PHCy}_{2}(3 \mathrm{mmol})$ in $30 \mathrm{~mL}$ of THF and $30 \mathrm{~mL}$ of water was added under nitrogen. A slight turbidity and color intensification could be 
observed in the reaction mixture. A solution of $0.90 \mathrm{~g}(24 \mathrm{mmol})$ of $\mathrm{NaBH}_{4}$ in $30 \mathrm{~mL}$ of water was added, and the solution turned black. After stirring for $3 \mathrm{~h}, 70 \mathrm{~mL}$ of toluene was added in order to separate the organic from the aqueous phase. The organic solvent was evaporated yielding a black solid. The solid was suspended in acetonitrile $(20 \mathrm{~mL})$, then vacuum filtered and washed with more acetonitrile $(100 \mathrm{~mL})$ on a fine frit. Yield $=368 \mathrm{mg}, 47 \%$

${ }^{1} \mathrm{H}$ NMR $\left(\mathrm{C}_{6} \mathrm{D}_{6}\right): \delta$ 3.2-1.2 (broad peaks)

${ }^{31} \mathrm{P}\left\{{ }^{1} \mathrm{H}\right\} \operatorname{NMR}\left(\mathrm{C}_{6} \mathrm{D}_{6}\right): \delta 54.0\left(\left[\mathrm{Au}\left(\mathrm{PCy}_{2}\right)\right]_{\mathrm{n}}\right)$

TEM: $\mathrm{d}(\mathrm{nm}): 1.67 \pm 0.40$

TGA: $75.1 \%$ Au, Au:P ratio $=3: 1$

XPS: Au:P = 4.5:1

To separate $\left[\mathrm{Au}\left(\mathrm{PCy}_{2}\right)\right]_{n}$ from $\mathrm{Au}_{x}\left(\mathrm{PCy}_{2}\right)_{y}$, a sample of $99 \mathrm{mg}$ of as-synthesized $\mathrm{Au}_{\mathrm{x}}\left(\mathrm{PCy}_{2}\right)_{\mathrm{y}}$ was dissolved in $3 \mathrm{~mL}$ of toluene and loaded onto a silica column (19 $\mathrm{x} 400$ $\mathrm{mm}$ ). $500 \mathrm{~mL}$ of a 4:1 mixture of hexane and toluene was used to separate the oligomer impurity from the cluster. The eluted solution was clear. Solvent evaporation from the eluted fraction yielded $14 \mathrm{mg}$ of $\left[\mathrm{Au}\left(\mathrm{PC} y_{2}\right)\right]_{n}\left({ }^{31} \mathrm{P}\left\{{ }^{1} \mathrm{H}\right\} \operatorname{NMR}\left(\mathrm{C}_{6} \mathrm{D}_{6}\right): \delta 54.1,48.1\right)$. The column was washed with ethanol and ethyl acetate until the eluted solution turned from black to a light brownish color. Most of the cluster remained on the column.

Cluster recovery was only $12 \mathrm{mg}$ of impure material, the amount being too small to allow further recrystallization. $\left({ }^{31} \mathrm{P}\left\{{ }^{1} \mathrm{H}\right\} \operatorname{NMR}\left(\mathrm{C}_{6} \mathrm{D}_{6}\right): \delta 127.8\right.$ (unknown), 48.1 (probably $\mathrm{PHCy}_{2}(\mathrm{O})$ - this peak showed $\mathrm{P}-\mathrm{H}$ coupling while the similar peak in $\left[\mathrm{Au}\left(\mathrm{PCy}_{2}\right)\right]_{n}$ did not show any $\mathrm{P}-\mathrm{H}$ coupling)). The material after column chromatography showed an average gold core diameter of $d_{\text {TEM }}(\mathrm{nm}): 1.42 \pm 0.37 \mathrm{~nm}$.

$\mathrm{Au}_{\mathrm{x}}\left(\mathbf{P}(\mathrm{t}-\mathrm{Bu})_{2}\right)_{\mathrm{y}}(\mathbf{4}) \mathrm{To}$ a solution of $1.181 \mathrm{~g}(3 \mathrm{mmol})$ of $\mathrm{HAuCl}_{4} \cdot 3 \mathrm{H}_{2} \mathrm{O}$ in $120 \mathrm{~mL}$ of THF and $75 \mathrm{~mL}$ of water, $\mathrm{PH}(\mathrm{t}-\mathrm{Bu})_{2}(0.439 \mathrm{~g}, 3 \mathrm{mmol})$ in $60 \mathrm{~mL}$ of a $1: 1 \mathrm{THF} /$ water mixture was added. No change in color could be observed. After stirring for $10 \mathrm{~min}$, a solution of $0.90 \mathrm{~g}$ (24 mmol, 8 equiv) of $\mathrm{NaBH}_{4}$ in $30 \mathrm{~mL}$ of water was added. The color of the solution turned dark red/brown. After $3 \mathrm{~h}$ of stirring a mixture of $120 \mathrm{~mL}$ of toluene and $50 \mathrm{~mL}$ of water was added and the organic phase was separated from the aqueous one. The organic solvent was evaporated at $40{ }^{\circ} \mathrm{C}$ to yield a black solid. The solid was suspended in $10 \mathrm{~mL}$ of acetonitrile, then filtered under vacuum and washed with $70 \mathrm{~mL}$ of acetonitrile. Yield $=328 \mathrm{mg}, 46 \%$.

${ }^{1} \mathrm{H}$ NMR $\left(\mathrm{C}_{6} \mathrm{D}_{6}\right): \delta 1.6$ (broad peak and sharp peak)

${ }^{31} \mathrm{P}\left\{{ }^{1} \mathrm{H}\right\} \operatorname{NMR}\left(\mathrm{C}_{6} \mathrm{D}_{6}\right): \delta 115.6,104.9,93.6\left[\mathrm{Au}\left(\mathrm{P}(\mathrm{t}-\mathrm{Bu})_{2}\right)\right]_{\mathrm{n}}$

TEM: $\mathrm{d}(\mathrm{nm})=1.96 \pm 0.49$

TGA: $83.62 \%$ Au, Au:P ratio $=3.8: 1$

XPS: $A u: P=4.4: 1$

In order to separate $\left[\mathrm{Au}\left(\mathrm{P}(\mathrm{t}-\mathrm{Bu})_{2}\right)\right]_{\mathrm{n}}$ from $\mathrm{Au}_{\mathrm{x}}\left(\mathrm{P}(\mathrm{t}-\mathrm{Bu})_{2}\right)_{\mathrm{y}}$, a sample of $128 \mathrm{mg}$ of assynthesized material was dissolved in $3 \mathrm{~mL}$ of toluene and loaded onto a silica column $(19 \times 400 \mathrm{~mm}) .500 \mathrm{~mL}$ of a $4: 1$ mixture of hexane and toluene was used to separate the oligomer impurity from the cluster. The eluted solution was clear. Solvent 
evaporation from the eluted fractions yielded a white solid $\left({ }^{31} \mathrm{P}\left\{{ }^{1} \mathrm{H}\right\} \operatorname{NMR}\left(\mathrm{C}_{6} \mathrm{D}_{6}\right): \delta 114.0\right.$, 104.8, 49.5). Recovery was $11 \mathrm{mg}, 8 \%$. The column was eluted with ethyl acetate and ethanol, giving, after solvent evaporation, a black solid, which still showed the presence of $\left[\mathrm{Au}\left(\mathrm{P}(\mathrm{t}-\mathrm{Bu})_{2}\right)\right]_{n}$ as impurity $\left({ }^{31} \mathrm{P}\left\{{ }^{1} \mathrm{H}\right\}\right.$ NMR $\left.\left(\mathrm{C}_{6} \mathrm{D}_{6}\right): \delta 107.3,104.9\right)$; separation of the cluster and oligomers was not achieved. The gold core diameters remained the same after column chromatography $\left(\mathrm{d}_{\mathrm{TEM}}(\mathrm{nm})=1.99 \pm 0.50\right)$.

In a similar reaction (starting with $1 \mathrm{mmol} \mathrm{HAuCl}_{4} \cdot 3 \mathrm{H}_{2} \mathrm{O}$ ) with a longer reaction time $(24 \mathrm{~h}),\left[\mathrm{Au}\left(\mathrm{P}(\mathrm{t}-\mathrm{Bu})_{2}\right)\right]_{\mathrm{n}}$ was still present and no further characterization was attempted.

\section{Monitoring Cluster Synthesis by ${ }^{31}$ P NMR Spectroscopy}

$\mathrm{Au}_{\mathrm{x}}\left(\mathrm{PMes}_{2}\right)_{\mathrm{y}}$ (1) To a solution of $0.32 \mathrm{~g}(0.8 \mathrm{mmol})$ of $\mathrm{HAuCl}_{4} \cdot 3 \mathrm{H}_{2} \mathrm{O}$ in $40 \mathrm{~mL}$ of THF and $25 \mathrm{~mL}$ of water, $0.270 \mathrm{~g}(1 \mathrm{mmol})$ of $\mathrm{PHMes}_{2}$ in $20 \mathrm{~mL}$ of a 1:1 mixture of $\mathrm{THF} /$ water were added and stirred for $10 \mathrm{~min}$. The solution before and after phosphine addition was very acidic as assayed with $\mathrm{pH}$ paper. At this stage of the reaction (solution A), the ${ }^{31} \mathrm{P}\left\{{ }^{1} \mathrm{H}\right\}$ NMR spectrum showed four peaks: $\delta 76.6$ (PCIMes 2$),{ }^{4} 45.0$ (unknown), $9.0\left(\mathrm{PHMes}_{2}(\mathrm{O})\right),{ }^{5}$ and $-57\left(\mathrm{Au}\left(\mathrm{PHMes}_{2}\right)(\mathrm{Cl})\right) .^{6}$

Slightly different results were obtained when $31 \mathrm{mg}(0.09 \mathrm{mmol})$ of $\mathrm{HAuCl}_{4} \cdot 3 \mathrm{H}_{2} \mathrm{O}$ and $27 \mathrm{mg}(0.1 \mathrm{mmol})$ of $\mathrm{PHMes}_{2}$ were dissolved in a mixture of $0.4 \mathrm{~mL}$ of THF and 0.25 $\mathrm{mL}$ of water in an NMR tube (reaction B). This time a peak at $35.5 \mathrm{ppm}$ was observed that was not present in solution A. When reaction $B$ was done only in THF, with a few drops of water to dissolve the gold salt, no $\mathrm{PHMes}_{2}(\mathrm{O})$ was observed in the ${ }^{31} \mathrm{P} \mathrm{NMR}$ spectrum. In both cases, after leaving the reaction mixture overnight in the NMR tube, the peak at 45.0 disappeared, and another peak at 34.9 increased in intensity. Probably the ${ }^{31} \mathrm{P}$ NMR spectrum of solution A did not show any peak at $35.5 \mathrm{ppm}$, because the solution was too dilute, and the compound was present only in a small amount.

To solution $\mathrm{A}, 0.30 \mathrm{~g}(8 \mathrm{mmol})$ of $\mathrm{NaBH}_{4}$ in $10 \mathrm{~mL}$ of water was added and the solution turned black. Black particles deposited on the bottom of the NMR tube and the only observable peak in the ${ }^{31} \mathrm{P}\left\{{ }^{1} \mathrm{H}\right\}$ NMR spectrum was at $8.4 \mathrm{ppm}$, due to $\mathrm{PHMes}_{2}(\mathrm{O})$. After the reaction mixture was stirred for $3 \mathrm{~h}$, about $75 \mathrm{~mL}$ of toluene were added to separate the organic layer from the aqueous one. The two layers were separated using cannula filtration in order to remove all insoluble impurities present in the toluene layer. The organic layer was washed with $\sim 75 \mathrm{~mL}$ of water and then the solvent was pumped off with heating at $45^{\circ} \mathrm{C}$, yielding a black solid. The solid was washed in the glovebox with acetonitrile.

$A^{31} \mathrm{P}\left\{{ }^{1} \mathrm{H}\right\}$ NMR spectrum was taken before and after washing the material. Before washing: ${ }^{31} \mathrm{P}\left\{{ }^{1} \mathrm{H}\right\}$ NMR (toluene): $\delta 6.8\left(\mathrm{PHMes}_{2}(\mathrm{O})\right)$, -92.3 $\left(\mathrm{PHMes}_{2}\right)$.

After washing: ${ }^{31} \mathrm{P}\left\{{ }^{1} \mathrm{H}\right\}$ NMR (toluene): $\delta-21.3,-34.0\left(\left[\mathrm{Au}\left(\mathrm{PMes}_{2}\right)\right]_{\mathrm{n}}\right)$.

The phosphine and phosphine oxide were removed, but the oligomer impurities were still present, and probably couldn't be observed in the spectrum of the unwashed material due to the other intense peaks. 
$\mathrm{Au}_{\mathrm{x}}\left(\mathrm{PCy}_{2}\right)_{\mathrm{y}}$ (3) Under $\mathrm{N}_{2}$, to $32 \mathrm{mg}(0.08 \mathrm{mmol})$ of $\mathrm{HAuCl}_{4} \bullet 3 \mathrm{H}_{2} \mathrm{O}, 20 \mathrm{mg}(0.1$ $\mathrm{mmol}$ ) of $\mathrm{PHCy}_{2}$ in $\sim 1 \mathrm{~mL}$ of THF were added in a NMR tube. As in the related experiment with $\mathrm{PHMes}_{2}$, formation of the chlorophosphine $\mathrm{PCy}{ }_{2} \mathrm{Cl}$ and a $\mathrm{Au}(\mathrm{I})$ complex, as well as unidentified materials, were observed.

${ }^{31} \mathrm{P}\left\{{ }^{1} \mathrm{H}\right\}$ NMR (THF): $\delta 117.0\left(\mathrm{PCy}_{2} \mathrm{Cl}\right.$, identified by spiking the reaction mixture with this commercially available compound), 76.5 (unknown), 54.1 (unknown), 12.4 $\left(\mathrm{Au}\left(\mathrm{PHCy}_{2}\right)(\mathrm{Cl})\right)$. $^{6}$

$\mathrm{Au}_{\mathrm{x}}\left(\mathbf{P}(\mathrm{t}-\mathrm{Bu})_{2}\right)_{\mathrm{y}}(4)$ Under $\mathrm{N}_{2}$ to $0.032 \mathrm{~g}(0.1 \mathrm{mmol})$ of $\mathrm{HAuCl}_{4} \bullet 3 \mathrm{H}_{2} \mathrm{O}, 15 \mathrm{mg}(0.1$ $\mathrm{mmol})$ of $\mathrm{PH}(\mathrm{t}-\mathrm{Bu})_{2}$ in $\sim 1 \mathrm{~mL}$ of THF were added in a NMR tube.

${ }^{31} \mathrm{P}\left\{{ }^{1} \mathrm{H}\right\}$ NMR $(\mathrm{THF}): \delta 143.6\left(\mathrm{P}(\mathrm{t}-\mathrm{Bu})_{2} \mathrm{Cl}\right.$, identified by spiking the reaction mixture with this commercially available compound), 91.1 (perhaps the oligomer $\left.\left[\mathrm{AuP}(\mathrm{t}-\mathrm{Bu})_{2}\right]_{n}\right)$, $48.9\left(\mathrm{Au}\left(\mathrm{PH}(\mathrm{t}-\mathrm{Bu})_{2}\right) \mathrm{Cl}\right){ }^{7}$

\section{Reactions of the Clusters with Dodecanethiol}

General procedure for "place-exchange" reactions. Treatment of MPCs with dodecanethiol. Under nitrogen, a sample of Au-phosphido MPC (typically 10-30 mg) in $1 \mathrm{~mL}$ of toluene was treated with an excess of dodecanethiol (typically $\geq 10$ equiv). The mixture was placed in an NMR tube and the progress of the reaction was monitored by ${ }^{31} \mathrm{P}$ NMR.

Because the as-prepared MPC samples contained the oligomers $\left[\mathrm{Au}\left(\mathrm{PR}_{2}\right)\right]_{\mathrm{n}}$ as impurities, we also investigated the reaction of these oligomers with dodecanethiol. In a typical NMR-tube reaction, a solution of $20-30 \mathrm{mg}$ of the oligomer $\left(4-7 \times 10^{-2} \mathrm{mmol}\right)$ in $\sim 1$ $\mathrm{mL}$ of toluene was treated with $100-150 \mathrm{mg}$ of $\mathrm{C}_{12} \mathrm{H}_{25} \mathrm{SH}$ (0.5-0.7 mmol, $\sim 10-15$ equiv) and the progress of the reaction was monitored by ${ }^{31} \mathrm{P}$ NMR at room temperature.

The alkylphosphido oligomers $\left[\mathrm{Au}\left(\mathrm{PC} y_{2}\right)\right]_{n}$ and $\left[\mathrm{Au}\left(\mathrm{P}(\mathrm{t}-\mathrm{Bu})_{2}\right)\right]_{n}$ did not react under these conditions.

$[\mathrm{Au}(\mathrm{PPhMes})]_{\mathrm{n}}$ reacted relatively quickly. After $2 \mathrm{~h}$, besides the peaks due to the oligomer, a peak due to the free phosphine was present. ${ }^{31} \mathrm{P}\left\{{ }^{1} \mathrm{H}\right\}$ NMR (toluene): $\delta-13.4$ $[\mathrm{Au}(\mathrm{P}(\mathrm{Ph})(\mathrm{Mes}))]_{\mathrm{n}},-14.5[\mathrm{Au}(\mathrm{P}(\mathrm{Ph})(\mathrm{Mes}))]_{n},-72.4(\mathrm{PH}(\mathrm{Ph})(\mathrm{Mes}))$ in an approximate ratio of $1: 1: 1$.

$\left[\mathrm{Au}\left(\mathrm{PMes}_{2}\right)\right]_{\mathrm{n}}$ reacted more slowly. After $3 \mathrm{~h}$, no reaction had occurred. After 4 days, the free phosphine was observed. ${ }^{31} \mathrm{P}\left\{{ }^{1} \mathrm{H}\right\} \mathrm{NMR}$ (toluene): $\delta$-91.8 $\left(\mathrm{PHMes}_{2}\right.$ )

Reaction of $\mathrm{Au}_{\mathrm{x}}\left(\mathrm{PMes}_{2}\right)_{\mathrm{y}}$ (1) with dodecanethiol a. Treatment of an asprepared sample of $\mathrm{Au}_{\mathrm{x}}\left(\mathrm{PMes}_{2}\right)_{\mathrm{y}}$ with dodecanethiol gave both $\mathrm{PHMes}_{2}$ and $\mathrm{PHMes}_{2}(\mathrm{O})$ in an approximate ratio of $3: 1 .{ }^{31} \mathrm{P}\left\{{ }^{1} \mathrm{H}\right\}$ NMR (toluene): $\delta 7.3\left(\mathrm{PHMes}_{2}(\mathrm{O})\right),-35.6$ $\left(\left[\mathrm{Au}\left(\mathrm{PMes}_{2}\right)\right]_{\mathrm{n}}\right),-91.9\left(\mathrm{PHMes}_{2}\right)$.

b. A similar reaction with a sample obtained after chromatography gave the same products, but with more of the oxide. $30 \mathrm{mg}$ of $\mathrm{Au}_{\mathrm{x}}\left(\mathrm{PMes}_{2}\right)_{\mathrm{y}}$ in $1 \mathrm{~mL}$ of toluene and 130 $\mathrm{mg}(0.64 \mathrm{mmol})$ of $\mathrm{C}_{12} \mathrm{H}_{25} \mathrm{SH}$ were mixed together in an NMR tube. After $1 \mathrm{~h},{ }^{31} \mathrm{P}\left\{{ }^{1} \mathrm{H}\right\}$ NMR (toluene): $\delta 5.8\left(\mathrm{PHMes}_{2}(\mathrm{O})\right)$. After $6 \mathrm{h:}{ }^{31} \mathrm{P}\left\{{ }^{1} \mathrm{H}\right\}$ NMR (toluene): $\delta 7.2\left(\mathrm{PHMes}_{2}(\mathrm{O})\right)$, $-91.3\left(\mathrm{PHMes}_{2}\right)$ in an approximate ratio of 3:1. 
Reaction of $\mathrm{Au}_{\mathrm{x}}(\mathrm{PPhMes})_{\mathrm{y}}$ (2) with dodecanethiol Place exchange reaction on different as-prepared $\mathrm{Au}_{\mathrm{x}}(\mathrm{P}(\mathrm{Ph})(\mathrm{Mes}))_{\mathrm{y}}$ samples showed on one occasion the presence of $\mathrm{PH}(\mathrm{Ph})(\mathrm{Mes})$ and $\mathrm{PH}(\mathrm{Ph})(\mathrm{Mes})(\mathrm{O})$ in an approximate 1:1 ratio, and on another occasion, only the presence of the phosphine oxide. Typically $\sim 20 \mathrm{mg}$ of as-synthesized cluster $\mathrm{Au}_{x}(\mathrm{P}(\mathrm{Ph})(\mathrm{Mes}))_{y}$ were treated with $\sim 70 \mathrm{mg}(0.35 \mathrm{mmol})$ of dodecanethiol.

On a chromatographed sample, place exchange with dodecanethiol resulted in the formation of $\mathrm{PH}(\mathrm{Ph})(\mathrm{Mes})$ and $\mathrm{PH}(\mathrm{Ph})(\mathrm{Mes})(\mathrm{O})$ in an approximate ratio of 1:2. 50 $\mathrm{mg}$ of $\mathrm{Au}_{\mathrm{x}}(\mathrm{P}(\mathrm{Ph})(\mathrm{Mes}))_{y}$ in $1 \mathrm{~mL}$ of toluene and $196 \mathrm{mg}(0.96 \mathrm{mmol})$ of $\mathrm{C}_{12} \mathrm{H}_{25} \mathrm{SH}$ were mixed in an NMR tube. After several hours, ${ }^{31} \mathrm{P}\left\{{ }^{1} \mathrm{H}\right\}$ NMR (toluene): $\delta 7.6$ $(\mathrm{PH}(\mathrm{Ph})(\mathrm{Mes})(\mathrm{O}))$. After four more days: ${ }^{31} \mathrm{P}\left\{{ }^{1} \mathrm{H}\right\}$ NMR: $\delta 7.8(\mathrm{PH}(\mathrm{Ph})(\mathrm{Mes})(\mathrm{O})), \quad-74.7$ $(\mathrm{PH}(\mathrm{Ph})(\mathrm{Mes}))$. The cluster product was precipitated with acetonitrile and filtered. ${ }^{1} \mathrm{H}$ NMR $\left(\mathrm{C}_{6} \mathrm{D}_{6}\right): 8.15$ (broad, PPhMes), 6.8 (broad, PPhMes), 2.17 (broad, PPhMes), 1.35, 0.95 (last two peaks broad, SR). These observations suggest that place-exchange was incomplete.

Reaction of $\mathrm{Au}_{\mathrm{x}}\left(\mathrm{PCy}_{2}\right)_{\mathrm{y}}(3)$ with dodecanethiol No reaction occurred when 10 $\mathrm{mg}$ of as-prepared cluster was treated with $20 \mathrm{mg}(0.1 \mathrm{mmol})$ of dodecanethiol at room temperature in toluene.

Reaction of $\mathrm{Au}_{\mathrm{x}}\left(\mathrm{P}(\mathrm{t}-\mathrm{Bu})_{2}\right)_{\mathrm{y}}$ (4) with dodecanethiol No reaction was observed when $37 \mathrm{mg}$ of as-prepared cluster was treated with $25 \mathrm{mg}(0.12 \mathrm{mmol})$ of dodecanethiol in toluene.

\section{Reactions of the Clusters with lodine}

Reaction of $\mathrm{Au}_{\mathrm{x}}\left(\mathrm{PMes}_{2}\right)_{\mathrm{y}}(\mathbf{1})$ with $\mathrm{I}_{2}$ All reactions with $\mathrm{I}_{2}$ were done in air. $15 \mathrm{mg}$ of as-prepared $\mathrm{Au}_{\mathrm{x}}\left(\mathrm{PMes}_{2}\right)_{\mathrm{y}}$ and $40 \mathrm{mg}(0.16 \mathrm{mmol})$ of $\mathrm{I}_{2}$ were dissolved in $1 \mathrm{~mL}$ of toluene. After 15 min ${ }^{31} \mathrm{P}\left\{{ }^{1} \mathrm{H}\right\}$ NMR (toluene): $\delta$-11.5. The same peak was observed when a mixture of impure $\mathrm{Au}_{\mathrm{x}}\left(\mathrm{PMes}_{2}\right)_{\mathrm{y}}$ and deliberately added $\left[\mathrm{Au}\left(\mathrm{PMes}_{2}\right)\right]_{n}$ was treated with $\mathrm{I}_{2}$. It was shown by independent synthesis (see below) to be due to the iodophosphine complex Au(PIMes 2$)(\mathrm{I})$.

Similarly, $4 \mathrm{mg}$ of chromatographed $\mathrm{Au}_{\mathrm{x}}\left(\mathrm{PMes}_{2}\right)_{\mathrm{y}}$ were treated with excess $\mathrm{I}_{2}$ in 1 $\mathrm{mL}$ of toluene. ${ }^{31} \mathrm{P}\left\{{ }^{1} \mathrm{H}\right\}$ NMR (toluene): $\delta 5.0$ (perhaps $\mathrm{PHMes}_{2}(\mathrm{O})$ ), -10.5 $\left(\mathrm{Au}\left(\mathrm{PIMes}_{2}\right)(\mathrm{I})\right)$.

Generation and Characterization of $\mathrm{Au}\left(\mathrm{PIMes}_{2}\right)(\mathrm{I}) 30 \mathrm{mg}(0.06 \mathrm{mmol})$ of $\left[\mathrm{Au}\left(\mathrm{PMes}_{2}\right)\right]_{n}$ were stirred with $29 \mathrm{mg}(0.11 \mathrm{mmol})$ of $\mathrm{I}_{2}$ in $1 \mathrm{~mL}$ of $\mathrm{C}_{6} \mathrm{D}_{6}$. The mixture turned instantly from a white slurry to a brown slurry and then to a red solution. After 15 min, ${ }^{1} \mathrm{H},{ }^{31} \mathrm{P}$ and ${ }^{13} \mathrm{C}$ NMR spectra of this mixture were taken.

${ }^{1} \mathrm{H} \mathrm{NMR}\left(\mathrm{C}_{6} \mathrm{D}_{6}\right): \delta 6.40(\mathrm{~d}, \mathrm{~J}=5, \mathrm{Ar}, 2 \mathrm{H}), 2.30(o-\mathrm{Me}, 12 \mathrm{H}), 1.90(p-\mathrm{Me}, 6 \mathrm{H})$

${ }^{31} \mathrm{P}\left\{{ }^{1} \mathrm{H}\right\} \operatorname{NMR}\left(\mathrm{C}_{6} \mathrm{D}_{6}\right): \delta-9.2$

${ }^{13} \mathrm{C}\left\{{ }^{1} \mathrm{H}\right\} \operatorname{NMR}\left(\mathrm{C}_{6} \mathrm{D}_{6}\right): \delta 141.8(\mathrm{~d}, \mathrm{~J}=2), 140.6(\mathrm{~d}, \mathrm{~J}=12), 131.8(\mathrm{~d}, \mathrm{~J}=9), 126.5(\mathrm{~d}, \mathrm{~J}=$ 36), $24.4(\mathrm{~d}, \mathrm{~J}=11, o-\mathrm{Me}), 20.6(p-\mathrm{Me})$ 
After $6 \mathrm{~h}$, the same sample showed peaks in the ${ }^{31} \mathrm{P}\left\{{ }^{1} \mathrm{H}\right\} \mathrm{NMR}$ spectrum at $\delta 114.7,8.0$, -9.1 . No obvious color change was observed, but a gold mirror formed on the walls of the NMR tube. Attempts to isolate the complex were unsuccessful.

Reaction of $\mathrm{Au}_{\mathrm{x}}(\mathrm{PPhMes})_{\mathrm{y}}(2)$ with $\mathrm{I}_{2}$ A sample of $11 \mathrm{mg}$ of chromatographed $\mathrm{Au}_{\mathrm{x}}(\mathrm{PPhMes})_{\mathrm{y}}$ (if the material is $\mathrm{Au}_{38}(\mathrm{PPhMes})_{16}, 9.7 \times 10^{-4} \mathrm{mmol} ; 0.02 \mathrm{mmol} \mathrm{PPhMes}$ ) was treated with $11 \mathrm{mg}(0.04 \mathrm{mmol})$ of $\mathrm{I}_{2}$ in $1 \mathrm{~mL}$ of $\mathrm{C}_{6} \mathrm{D}_{6}$. After $15 \mathrm{~min},{ }^{31} \mathrm{P}\left\{{ }^{1} \mathrm{H}\right\} \mathrm{NMR}$ $\left(\mathrm{C}_{6} \mathrm{D}_{6}\right): \delta 23.7$ (minor), 7.9 (major). The independent synthesis described below suggests that the major product is $\mathrm{Au}$ (PIPhMes)(I).

After 90 min, the same sample showed peaks in the ${ }^{31} \mathrm{P}\left\{{ }^{1} \mathrm{H}\right\}$ NMR spectrum at $\delta$ $50.7,42.1,31.6,20.7$. A black precipitate formed on the bottom of the NMR tube, while the solution had a red color from excess $I_{2}$. On the walls of the NMR tube a gold mirror appeared. The peaks observed had similar chemical shifts to those seen in the reaction between [Au(PPhMes) $]_{n}$ and iodine (see below). The decomposition of the $\delta 7.9$ compound (assigned to "Au(PIPhMes)(I)") appeared to take place more quickly in the presence of the cluster than in its original synthesis.

Similarly, $3 \mathrm{mg}$ of chromatographed $\mathrm{Au}_{\mathrm{x}}(\mathrm{PPhMes})_{\mathrm{y}}$ in $1 \mathrm{~mL}$ of toluene was treated with excess $\mathrm{I}_{2}{ }^{31} \mathrm{P}\left\{{ }^{1} \mathrm{H}\right\}$ NMR (toluene): $\delta 5.4$ (Au(PIPhMes)(I)), -22.9 (unidentified).

Au(PIPhMes)(I) $35 \mathrm{mg}(0.08 \mathrm{mmol})$ of $[\mathrm{Au}(\mathrm{PPhMes})]_{\mathrm{n}}$ in $1 \mathrm{~mL}$ of $\mathrm{C}_{6} \mathrm{D}_{6}$ were treated with $38 \mathrm{mg}(0.15 \mathrm{mmol})$ of $\mathrm{I}_{2}$. The reaction mixture changed from a white slurry to a dark red solution in a few minutes. After $15 \mathrm{~min},{ }^{1} \mathrm{H},{ }^{31} \mathrm{P}$ and ${ }^{13} \mathrm{C}$ NMR spectra were recorded.

${ }^{1} \mathrm{H}$ NMR $\left(\mathrm{C}_{6} \mathrm{D}_{6}\right): \delta$ 7.31-7.27 (m, Ar, 2H), 6.87-6.80 (m, Ar, 3H), $6.41(\mathrm{~d}, \mathrm{~J}=5, \mathrm{Ar}, 2 \mathrm{H})$, $2.31(\mathrm{Me}, 6 \mathrm{H}), 1.89(\mathrm{Me}, 3 \mathrm{H})$

${ }^{31} \mathrm{P}\left\{{ }^{1} \mathrm{H}\right\} \operatorname{NMR}\left(\mathrm{C}_{6} \mathrm{D}_{6}\right): \delta 42.0$ (minor), 28.6 (minor), 7.3 (major). The minor peaks are probably due to decomposition of the compound with a chemical shift of $7.3 \mathrm{ppm}$, assumed to be $\mathrm{Au}(\mathrm{PIPhMes})(\mathrm{I})$

${ }^{13} \mathrm{C}\left\{{ }^{1} \mathrm{H}\right\} \operatorname{NMR}\left(\mathrm{C}_{6} \mathrm{D}_{6}\right): \delta 144.3(\mathrm{~d}, \mathrm{~J}=13), 143.8,133.9(\mathrm{~d}, \mathrm{~J}=13), 132.0(\mathrm{~d}, \mathrm{~J}=9), 131.1$ (d, J = 15), $131.0(d, J=2.5), 130.7(d, J=40), 130.5(d, J=9), 129.4(d, J=30), 24.7$ $(d, J=13), 20.7$.

The same sample showed, after $6 \mathrm{~h}$, peaks in the ${ }^{31} \mathrm{P}\left\{{ }^{1} \mathrm{H}\right\} \mathrm{NMR}$ spectrum at $\delta$ 52.8, 43.0, 42.1, 28.8, 7.4, -23.3. A gold mirror formed on the walls of the NMR tube. Attempts to isolate the complex from similar reactions were unsuccessful.

Reaction of $\mathrm{Au}_{\mathrm{x}}\left(\mathrm{P}(\mathrm{t}-\mathrm{Bu})_{2}\right)_{\mathrm{y}}$ (4) with $\mathrm{I}_{2}$ To $92 \mathrm{mg}$ of $\mathrm{Au}_{\mathrm{x}}\left(\mathrm{P}(\mathrm{t}-\mathrm{Bu})_{2}\right)_{\mathrm{y}}$ (according to TGA analysis, the sample contains $84.7 \%$ Au and correspondingly $15.3 \%$ (14 mg, 0.1 mmol) $\mathrm{P}(\mathrm{t}-\mathrm{Bu})_{2}$ groups), $81 \mathrm{mg}(0.3 \mathrm{mmol})$ of $\mathrm{I}_{2}$ were added under nitrogen. The solution turned from black to dark red and $30 \mathrm{mg}$ of black insoluble material deposited on the bottom of the reaction flask. After $2 \mathrm{~h}$, the mixture was filtered and, from the filtrate, the solvent was evaporated, giving a black solid, which was sublimed at $40^{\circ} \mathrm{C}$ to remove $\mathrm{I}_{2}$, yielding $20 \mathrm{mg}(32 \%)$ of a dark yellow solid, identified as $\mathrm{Au}\left(\mathrm{PI}(\mathrm{t}-\mathrm{Bu})_{2}\right)(\mathrm{I})$ by its NMR spectra. ${ }^{3 b}{ }^{31} \mathrm{P}\left\{{ }^{1} \mathrm{H}\right)$ NMR $\left(\mathrm{C}_{6} \mathrm{D}_{6}\right): \delta 116.3,{ }^{1} \mathrm{H}$ NMR: $\delta 0.90(\mathrm{~d}, \mathrm{~J}=21)$. The mass balance 
of this reaction is poor due probably to losses of some material during the workup when working on such a small scale.

\section{References}

1. Bartlett, R. A.; Olmstead, M. M.; Power, P. P.; Sigel, G. A. Inorg. Chem. 1987, 26, 1941-1946.

2. Kovacik, I.; Wicht, D. K.; Grewal, N. S.; Glueck, D. S.; Incarvito, C. D.; Guzei, I. A.; Rheingold, A. L. Organometallics 2000, 19, 950-953.

3. (a) Stefanescu, D. M.; Yuen, H. F.; Glueck, D. S.; Golen, J. A.; Rheingold, A. L. Angew. Chem. Int. Ed. 2003, 42, 1046-1048. (b) Stefanescu, D. M.; Yuen, H. F.; Glueck, D. S.; Golen, J. A.; Zakharov, L. N.; Incarvito, C. D.; Rheingold, A. L. Inorg. Chem. 2003, 42, 8891-8901.

4. Bartlett, R. A.; Olmstead, M. M.; Power, P. P.; Sigel, G. A. Inorg. Chem. 1987, 26, 1941-1946.

5. Lindner, E.; Frey, G. Chem. Ber. 1980, 113, 2769-2778.

6. Schmidbaur, H.; Weidenhiller, G.; Aly, A. A. M.; Steigelmann, O.; Muller, G. Z. Naturforsch. B 1989, 44, 1503-1508.

7. Schmidbaur, H.; Aly, A. A. M. Z. Naturforsch. B 1979, 34, 23-26. See also reference 6. 